\title{
Safety analysis of early oral feeding after esophagectomy in patients complicated with diabetes
}

Zhisheng Jiang ${ }^{1,2 \dagger}$, Jing $\mathrm{LuO}^{2 \dagger}$, Mengqing $\mathrm{Xu}^{3 \dagger}$, Zhuangzhuang Cong ${ }^{2}$, Saiguang $\mathrm{Ji}^{2}$, Yifei Diao ${ }^{2}, \mathrm{Yang}_{\mathrm{Xu}}{ }^{2}$ and Yi Shen ${ }^{1,2^{*}}$

\begin{abstract}
Objective: To evaluate the safety of early oral feeding in patients with type II diabetes after radical resection of esophageal carcinoma.

Methods: The clinical data of 121 patients with type II diabetes who underwent radical resection of esophageal carcinoma in the department of cardiothoracic surgery of Jinling Hospital from January 2016 to December 2018 were retrospectively analyzed. According to the median time (7 days) of the first oral feeding after surgery, the patients were divided into early oral feeding group (EOF, feeding within 7 days after surgery, 67 cases) and late oral feeding group (LOF, feeding after 7 days, 54 cases). Postoperative blood glucose level, incidence of complications, nutritional and immune indexes, inflammatory indexes, normalized T12-SMA (the postoperative/preoperative ratio of vertical spinal muscle cross-sectional area at the 12th thoracic vertebra level) and QLQ-C30 (Quality Of Life Questionnaire) scores were recorded and compared in the two groups.

Results: There was no statistical difference in preoperative nutritional index and postoperative complication rates between the EOF and LOF group ( $p>0.05$ ). The postoperative nutritional index (ALB, PA, TRF, Hb) and immune index (IgA, IgG, IgM) of the EOF group were higher than those of the LOF group $(p<0.05)$, and the inflammatory indicators (CRP, IL-6) of the EOF group were significantly lower than those of the LOF group $(p<0.05)$. Moreover, postoperative T12-SMA variation and QLQ-C30 scores of the EOF group were higher than those in LOF group $(p<$ 0.05).
\end{abstract}

Conclusions: Early oral feeding is safe and feasible for patients with type II diabetes after radical resection of esophageal cancer, and it can improve short-term nutritional status and postoperative life quality of the patients.

Keywords: Esophageal cancer, Type II diabetes, Oral feeding, Nutritional status, Life quality

\footnotetext{
* Correspondence: dryishen@nju.edu.cn

'Zhisheng Jiang, Jing Luo and Mengqing Xu contributed equally to this

work.

'Bengbu Medical College, Bengbu, China

${ }^{2}$ Department of Cardiothoracic Surgery, Jinling Hospital, 305 East Zhongshan Road, Nanjing, China

Full list of author information is available at the end of the article
}

(c) The Author(s). 2021 Open Access This article is licensed under a Creative Commons Attribution 4.0 International License, which permits use, sharing, adaptation, distribution and reproduction in any medium or format, as long as you give appropriate credit to the original author(s) and the source, provide a link to the Creative Commons licence, and indicate if changes were made. The images or other third party material in this article are included in the article's Creative Commons licence, unless indicated otherwise in a credit line to the material. If material is not included in the article's Creative Commons licence and your intended use is not permitted by statutory regulation or exceeds the permitted use, you will need to obtain permission directly from the copyright holder. To view a copy of this licence, visit http://creativecommons.org/licenses/by/4.0/ The Creative Commons Public Domain Dedication waiver (http://creativecommons.org/publicdomain/zero/1.0/) applies to the data made available in this article, unless otherwise stated in a credit line to the data. 


\section{Introduction}

Esophageal cancer is one of the most common digestive malignancies worldwide, with morbidity and mortality rank the 7th and 6th among all malignancies, respectively. GLOBOCAN data showed that 572,000 new cases of esophageal cancer and 509,000 deaths were reported in 2018 over the worldwide [1]. The number of new cases and deaths of esophageal cancer in China ranks the first in the world, accounting for about $50 \%$ of the cases and deaths globally [2]. Surgical resection is the main treatment method for patients with esophageal cancer at present. However, the surgical method of esophageal cancer is complex with many postoperative complications, with the 5-year survival rate less than $30 \%$ [3].

It has been reported that diabetes may be an independent risk factor for the incidence of esophageal cancer [4]. As a metabolic disorder of glucose, protein and fat caused by defective insulin secretion or impaired biological function, diabetes are growing rapidly all over the world [5]. At present, about $10 \% \sim 20 \%$ of surgical patients are accompanied with diabetes, mainly type II diabetes [6]. For patients of esophageal cancer accompanied with type II diabetes, postoperative complications such as difficult incision healing, pulmonary infection and anastomotic fistula are more likely to occur, which remarkably increases the risk of complications after surgery [7-9]. It is of great significance to reduce the surgical risk of this group of patients.

Nutritional support for patients with esophagectomy is of great significance, especially for patients with malnutrition. However, the timing of oral intake after esophagectomy is still a bone of contention. Based on recent studies, more and more evidences prove that oral feeding is feasible and effective in the early postoperative period of digestive tract surgery $[10,11]$. Early oral feeding can reduce the stress response after esophagectomy, accelerate the recovery of intestinal function, and improve the short-term quality of life without increasing postoperative complications and motality [12, 13]. Nevertheless, few researches were reproted to explore the safety of early oral feeding after esophagectomy in patients complicated with type II diabetes. In this study, we compared the incidence of postoperative complications and index of nutrition, immune and inflammation after esophagectomy between early oral feeding group and late oral feeding group in patients complicated with type II diabetes. We aim to investigate the safety and effectiveness of early oral feeding on this kind of patients.

\section{Materials and methods}

\section{Patients}

Retrospective analysis was conducted on the clinical data of patients with esophageal cancer complicated with type
II diabetes who underwent radical resection in the cardiothoracic surgery department of Jinling Hospital from January 2016 to December 2018. Inclusion criteria was: (1) all patients were 18 years old or older; (2) esophageal squamous cell carcinoma was diagnosed pathologically after surgery; (3) all patients were diagnosed with type II diabetes as the following creteria:1) Typical diabetes symptoms (thirst, polydipsia, polyuria, polyphagia, unexplained weight loss) and random blood glucose $\geq 11.1$ $\mathrm{mmol} / \mathrm{L} ; 2$ ) Fasting blood glucose $\mathrm{FPG} \geq 7.0 \mathrm{mmol} / \mathrm{L} ; 3$ ) Blood glucose at $2 \mathrm{~h}$ of OGTT was $\geq 11.1 \mathrm{mmol} / \mathrm{L} ; 4$ ) HbA1c $\geq 6.5 \%$; (4) complete clinical data and follow-up information are available. Exclusion criteria was: (1) patients with severe heart disease and liver and kidney dysfunction; (2) severe coagulation dysfunction; (3) concurrent or previous history of other malignant tumors; (4) perioperative death. According to the median time (7 days) of the first oral feeding after surgery, the patients were divided into early oral feeding group (EOF, feeding within 7 days after surgery, 67 cases) and late oral feeding group (LOF, feeding after 7 days, 54 cases). And the patients were staged using the 8th edition of the TNM staging standard for esophageal cancer issued by the Union for International Cancer Control (UICC). Written informed consent was obtained from all patients, and protocols for this study were approved by the Ethics Committee of Jinling Hospital.

\section{Data acquisition}

By consulting the electronic medical record system, information of patients meeting the standard was collected, including preoperative clinical indicators (gender, age, body mass index, smoking and alcohol history, glycosylated hemoglobin (HbAlc), albumin, etc.), intraoperative indicators (operation mode, operation time, operative blood loss, etc.) and postoperative indicators (oral feeding time, oral food tolerance, blood glucose, complications, index of nutrition, immune and inflammation, TNM stage, differentiation degree and clinical outcome, etc.). Index of nutrition, immune and inflammation, weight change, quality of life score and T12-SMA were reviewed 1 month after discharge. Postoperative complications were graded according to the severity grading system (2009, ClavienDindo) and quality of life scores were obtained by QLQC30 questionnaire.

\section{Surgery methods}

After admission, all patients underwent routine gastroscopy, chest and abdomen $\mathrm{CT}$, electrocardiogram and pulmonary function examination to exclude surgery contraindications. Surgical methods include open surgery and minimally invasive surgery (including thoracoscopic radical esophagectomy and Da Vinci robot-assisted radical esophagectomy). 


\section{Glycemic management}

Preoperative blood glucose monitoring was conducted, of which blood glucose was measured $2 \mathrm{~h}$ before and after meals each day. The blood glucose value after meals was controlled below $7 \sim 11.1 \mathrm{mmol} / \mathrm{L}$, and the blood glucose was maitained stable for more than 3 days before the operation. After operation, blood glucose was monitored once a day at $6,9,11,14,17,20$ and 22 o 'clock. The blood glucose was adjusted by subcutaneous injection of ordinary insulin as to control it smoothly at $7.0 \sim 11.1 \mathrm{mmol} / \mathrm{L}$.

\section{Postoperative nutritional support}

Postoperative nutritional support was provided to patients in both groups according to the ESPEN (the guidelines of the European Society of Parenteral and Enteral Nutrition) and the guidelines of the American Nutrition Association. Patients in both groups received the same nutritional support after surgery. Supplemental Parenteral Nutrition (SPN) was used on the same day after surgery according to the "permissible low-calorie principle" [20-25 kcal/kg]. In addition, $500 \mathrm{ml} 5 \%$ glucose and sodium chloride injection was pumped through the nasoenteral nutrition tube or jejunal stoma tube $12 \mathrm{~h}$ after the operation. According to the patient's tolerance, enteral nutrition (EN) and perenteral nutrition (PN) preparation were combined with intravenous infusion within $24 \mathrm{~h}$ after the operation, with a total daily calories of $30 \mathrm{kcal} / \mathrm{kg}$. Patients began to drink water after anus exhaust defecation, and gradually shifted to liquid food.

\section{Home nutrition}

At discharge, the patients were given a follow-up table of home nutrition and were required to record the patient's weight, diet and food intake, gastrointestinal reactions and other information every day. Patients received home enteral nutrition through oral nutrition solution or jejunostomy tube every day. On the basis of normal diet of patients, professional dietitians calculated the amount of extra nutrition needed, and conducted dietary guidance by telephone.

\section{Statistical analysis}

Statistical software SPSS 23.0 was used to analyze the data. Quantitative data were presented as mean and standard deviation (Mean \pm SD). Independent sample $t$ test was used for inter-group comparison. And chi-square test was used for inter-group comparison. $P<0.05$ indicated statistically significant difference $\left({ }^{*} p<0.05 ;{ }^{* *} p<0.01 ;{ }^{* * * *} p<0.001\right)$.

\section{Results}

\section{General information}

A total of 121 patients were included in this study. According to the median time (7 days) of first postoperative oral feeding time, they were divided into EOF group (67 cases) and LOF group (54 cases). Among them, there were 50 males and 17 females in EOF group, with an average age of $(63.37 \pm 7.49)$ years. There were 41 males and 13 females in the LOF group, with an average age of $(63.74 \pm 7.22)$ years. The mean duration of diabetes was $4.96 \pm 2.56$ years in the EOF group and $5.27 \pm 2.82$ years in the LOF group. There were no statistically significant differences in gender, age and body mass index between the two groups $(p>0.05)$ (Table 1$)$.

\section{Blood glucose levels}

Within 7 days after the operation, the blood glucose levels in EOF group and LOF group fluctuated from 6.86 to $11.47 \mathrm{mmol} / \mathrm{L}$ and 6.52 to $10.88 \mathrm{mmol} / \mathrm{L}$, respectively. The blood glucose level varied greatly in the first 2 days after surgery, but both group showed similar blood glucose levels after surgery $(p>0.05)$ (Fig. 1a). It suggested that EOF might not affect the control of blood glucose.

\section{Immune index}

The immune index of the two groups showed a decreasing trend after the operation, with in POD 3 falling to the lowest and then slowly recovering. There was no significant difference on immune index between the two groups in the preoperative day, POD 1 and POD $3(p>$ $0.05)$. However, EOF group showed higher IgA (1.32 \pm 0.53 VS $1.13 \pm 0.41, p=0.032)$ level in POD7 and higher IgA $(1.91 \pm 0.78$ VS $1.56 \pm 0.65, p=0.009), \operatorname{IgG}(12.64 \pm$ $2.86 \mathrm{VS} 11.36 \pm 2.71, p=0.014)$ and $\operatorname{IgM}(1.39 \pm 0.42 \mathrm{VS}$ $1.22 \pm 0.37, p=0.021$ ) level in POD30 (Table 2) (Fig. 1b). These results indicated that EOF was conducive to the restoration of immunity.

\section{Nutrition index}

Similarly, nutrient level declined sharply after surgery and slowly rebounded in POD3. There was no significant difference in nutrition index between the two groups in the preoperative day, POD 1 and POD $3(p>$ $0.05)$. EOF group presented higher PA $(208.62 \pm 27.12$ VS 195.37 $\pm 32.78, p=0.016)$ level in POD 7 and higher ALB $(39.67 \pm 3.16$ VS $38.14 \pm 3.83, \quad p=0.018), \quad$ PA $(248.96 \pm 47.85$ VS $211.38 \pm 55.23, \quad p=0.004), \quad$ TRF $(1.89 \pm 0.42$ VS $1.72 \pm 0.35, p=0.019)$ and $\mathrm{Hb}(119.95 \pm$ 14.02 VS 112.06 $\pm 18.73, p=0.009)$ level in POD 30 (Table 3) (Fig. 1c). This given us a hint that EOF could improve the nutritional status of patients after surgery. 
Table 1 General information of included patients

\begin{tabular}{|c|c|c|c|}
\hline Characteristics & EOF $(n=67)$ & LOF $(n=54)$ & $p$ value \\
\hline Gender & & & 0.869 \\
\hline Male & 50 & 41 & \\
\hline Female & 17 & 13 & \\
\hline Age (years) & $63.37 \pm 7.49$ & $63.74 \pm 7.22$ & 0.784 \\
\hline BMI (kg /m2) & $22.69 \pm 2.19$ & $23.12 \pm 2.61$ & 0.326 \\
\hline Underlying diseases & & & 0.556 \\
\hline Yes & 14 & 9 & \\
\hline No & 53 & 45 & \\
\hline Smoking history & & & 0.673 \\
\hline Yes & 41 & 31 & \\
\hline No & 26 & 23 & \\
\hline Alcohol history & & & 0.681 \\
\hline Yes & 44 & 36 & \\
\hline No & 23 & 18 & \\
\hline Neoadjuvant chemotherapy & & & 0.828 \\
\hline Yes & 7 & 5 & \\
\hline No & 60 & 49 & \\
\hline Preoprative HbAlc & $7.58 \pm 1.36$ & $7.91 \pm 1.64$ & 0.228 \\
\hline $\begin{array}{l}\text { Duration of diabetes } \\
\text { history (years) }\end{array}$ & $4.96 \pm 2.56$ & $5.27 \pm 2.82$ & 0.528 \\
\hline Operation type & & & 0.324 \\
\hline Minimally invasive & 49 & 35 & \\
\hline Open & 18 & 19 & \\
\hline Identical parts & & & 0.625 \\
\hline Cervical & 51 & 41 & \\
\hline Intrathoracic & 16 & 13 & \\
\hline Operating time (min) & $208.27 \pm 36.82$ & $215.64 \pm 41.52$ & 0.303 \\
\hline $\begin{array}{l}\text { Intraoperative blood } \\
\text { loss (ml) }\end{array}$ & $227.62 \pm 50.26$ & $239.81 \pm 55.83$ & 0.209 \\
\hline Tumor location & & & 0.284 \\
\hline Upper & 4 & 6 & \\
\hline Middle & 45 & 29 & \\
\hline Lower & 18 & 19 & \\
\hline $\begin{array}{l}\text { Number of dissected lymph } \\
\text { nodes }\end{array}$ & $18.62 \pm 11.16$ & $20.34 \pm 9.86$ & 0.377 \\
\hline $\begin{array}{l}\text { Degree of tumor } \\
\text { differentiation }\end{array}$ & & & 0.439 \\
\hline Well & 9 & 10 & \\
\hline Moderately & 40 & 26 & \\
\hline Poorly & 18 & 18 & \\
\hline TNM stage & & & 0.307 \\
\hline $\mathrm{T} 1$ & 13 & 7 & \\
\hline $\mathrm{T} 2$ & 34 & 24 & \\
\hline T3 & 20 & 23 & \\
\hline
\end{tabular}

\section{Inflammatory index}

There was no significant difference in inflammatory index between the two groups in the preoperative day, POD 1 and POD $3(p>0.05)$. Both CRP and IL-6 increased after surgery, of which CRP reached peak in POD 3 and IL-6 in POD 1. EOF group had lower CRP and IL-6 level in POD 7 (CRP, $47.58 \pm 25.72$ VS $60.87 \pm$ 30.26, $p=0.01$; IL-6, $19.34 \pm 12.67$ VS 26.19 $\pm 10.73, p=$ $0.002)$ and POD $30(\mathrm{CRP}, 6.13 \pm 13.25 \mathrm{VS} 13.57 \pm 18.96$, $p=0.013$; IL-6, $5.86 \pm 6.34$ VS $10.35 \pm 5.82, p=0.0001)$ (Table 4) (Fig. 1d). It revealed that EOF could promote the recovery of inflammatory response.

\section{Postoperative complications}

Total complications in EOF group and LOF group were 25 cases (37.31\%) and 21 cases (38.87\%), respectively. The incidence of anastomotic fistula, incision infection and pulmonary infection complications in EOF group and LOF group were respectively (8.96\% VS 9.26\%), (7.46\% VS 5.56\%) and (7.46\% VS 9.26\%), and there was no statistically significant difference in the incidence of these three complications between the two groups $(p>$ 0.05) (Table 5). This showed that EOF might not increase the incidence of complications.

\section{Body weight loss and T12-SMA variation}

The body weight loss of patients in EOF group was lower than that in LOF group in POD $30(4.23 \pm 2.06 \mathrm{VS}$ $5.56 \pm 2.86, p=0.004$ ) (Fig. 2a). Moreover, T12-SMA variation (the post/pre ratio) was greater in the EOF group $(0.87 \pm 0.25$ VS $0.79 \pm 0.16, p=0.043)$ (Fig. $2 b-c)$. These results suggested that EOF could inhibited the loss of body weight and skeletal muscle caused by surgery.

\section{EORTC QLQ-C30 scores}

As shown in Table S1, there was no statistical difference in preoperative QLQ-C30 scores between the two groups. However, 30 days after surgery, the overall health of patients in EOF group was better than that in LOF group $(61.33 \pm 10.18$ VS 53.96 $\pm 14.87, p=0.001)$. And in the functional rating scale, the EOF group was better than the LOF group in terms of physical function $(59.12 \pm 17.74$ VS $50.35 \pm 16.48, p=0.006)$ and emotional function $(61.17 \pm 15.73$ VS $54.98 \pm 12.61, \quad p=0.021)$. Moreover, on score of symptoms rating scale, fatigue $(50.82 \pm 19.47$ VS $59.16 \pm 18.04, p=0.017)$, loss of appetite $(27.67 \pm 20.36$ VS $38.62 \pm 21.68, p=0.005)$ and diarrhea $(22.96 \pm 16.08$ VS $31.32 \pm 17.79, p=0.008)$ of the EOF group were lower than those of the LOF group (Table 6). These results showed that EOF might reduce the incidence of some certain symptoms and improve the quality life of patients. 


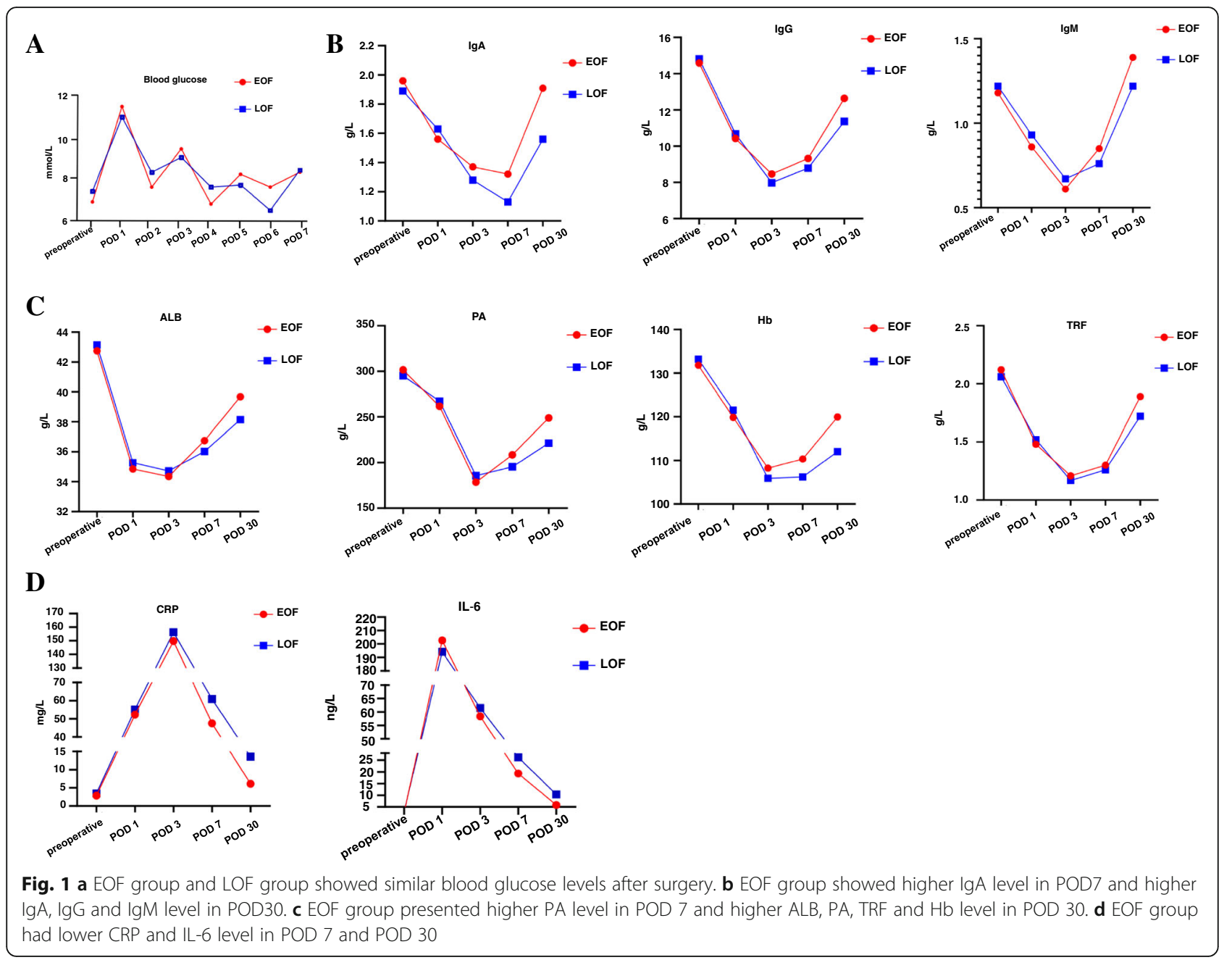

\section{Discussion}

Esophagectomy is the predominant treatment for patients with esophageal cancer at present. Due to the complexity, large trauma and long duration of the surgery, patients are at a state of stress and have a high incidence of postoperative complications, including anastomotic fistula, pulmonary infection, respiratory failure, etc. [14]. Patients with esophageal cancer usually have malnutrition for its difficult swallowing and tumor consumption. And for patients complicated with type II diabetes, the blood glucose fluctuates widely and stress response is violent, thus increasing the inflammatory reaction, impairing the immune system and decreasing tissue repair ability [15]. Therefore, esophageal cancer patients complicated with type II diabetes are more likely to suffer postoperative complications and tend to have a poorer life quality $[16,17]$. It is of great importance to reduce the surgical risk and improve the prognosis of these group of patients.

With the development of the concept of Enhanced Recovery After Surgery (ERAS) and its application in the field of surgery, patients can better endure surgical stress and recover more quickly. The core theory of ERAS is to allow patients to return to the physiological state, to relieve the body's stress state, and to accelerate the early recovery of patients as soon as possible after surgery [18, 19]. In the traditional surgical treatment scheme for esophageal cancer, clinicians often worry that the early postoperative oral feeding may increase the incidence of anastomotic leakage. Hence, patients need to perform routine gastrointestinal decompression and fasting for 5-7 days after surgery [20]. For patients complicated with diabetes, anastomotic healing tends to be delayed, so postoperative fasting time of patients is usually prolonged in clinical practice [21]. However, in the treatment mode of ERAS, early oral feeding is the most physiological way of nutrition delivery, which has been regarded as one of the most crucial measures [22]. Incresing evidences have shown that early oral feeding after digestive tract surgery was safe and feasible, which did not increase the incidence of postoperative complications such as anastomotic fistula and 
Table 2 Immune index of the two groups

\begin{tabular}{|c|c|c|c|}
\hline Immune index & EOF $(n=67)$ & LOF $(n=54)$ & $p$ value \\
\hline \multicolumn{4}{|l|}{ Preoperative } \\
\hline $\operatorname{lgA} /(\mathrm{g} / \mathrm{L})$ & $1.96 \pm 0.85$ & $1.89 \pm 0.91$ & 0.663 \\
\hline $\operatorname{lgG} /(\mathrm{g} / \mathrm{L})$ & $14.59 \pm 3.22$ & $14.81 \pm 2.96$ & 0.699 \\
\hline $\lg M /(g / L)$ & $1.18 \pm 0.33$ & $1.22 \pm 0.37$ & 0.531 \\
\hline \multicolumn{4}{|l|}{ POD 1} \\
\hline $\lg A /(g / L)$ & $1.56 \pm 0.69$ & $1.63 \pm 0.55$ & 0.547 \\
\hline $\operatorname{lgG} /(\mathrm{g} / \mathrm{L})$ & $10.42 \pm 2.16$ & $10.68 \pm 2.83$ & 0.568 \\
\hline $\operatorname{lgM} /(g / L)$ & $0.86 \pm 0.27$ & $0.93 \pm 0.21$ & 0.121 \\
\hline \multicolumn{4}{|l|}{ POD 3} \\
\hline $\operatorname{lgA} /(\mathrm{g} / \mathrm{L})$ & $1.37 \pm 0.58$ & $1.28 \pm 0.46$ & 0.355 \\
\hline $\lg G /(g / L)$ & $8.46 \pm 2.63$ & $7.98 \pm 2.14$ & 0.281 \\
\hline $\operatorname{lgM} /(g / L)$ & $0.61 \pm 0.19$ & $0.67 \pm 0.23$ & 0.119 \\
\hline \multicolumn{4}{|l|}{ POD 7} \\
\hline $\lg A /(g / L)$ & $1.32 \pm 0.53$ & $1.13 \pm 0.41$ & $0.032^{*}$ \\
\hline $\operatorname{lgG} /(\mathrm{g} / \mathrm{L})$ & $9.32 \pm 2.13$ & $8.79 \pm 2.27$ & 0.189 \\
\hline $\operatorname{lgM} /(g / L)$ & $0.85 \pm 0.22$ & $0.76 \pm 0.29$ & 0.055 \\
\hline \multicolumn{4}{|l|}{ POD 30} \\
\hline $\lg A /(g / L)$ & $1.91 \pm 0.78$ & $1.56 \pm 0.65$ & $0.009^{*}$ \\
\hline $\operatorname{lgG} /(\mathrm{g} / \mathrm{L})$ & $12.64 \pm 2.86$ & $11.36 \pm 2.71$ & $0.014^{*}$ \\
\hline $\operatorname{lgM} /(\mathrm{g} / \mathrm{L})$ & $1.39 \pm 0.42$ & $1.22 \pm 0.37$ & $0.021^{*}$ \\
\hline
\end{tabular}

pulmonary infection, and meanwhile benefited patients for their long-term quality of life [23-25]. At present, there are few reports on the safety and benefit of early oral feeding in patients of esophageal cancer complicated with type II diabetes.

Patients with esophageal cancer are often accompanied by malnutrition due to different degrees of eating obstruction and chronic consumption, and the high catabolism caused by surgical trauma and post-operative stress reaction will further aggravate malnutrition and immunosuppression [26]. In this study, we used ALB, $\mathrm{PA}, \mathrm{TRF}, \mathrm{Hb}$ to evaluate the nutrition status and IgA, IgG, IgM to measre the immune status, and results revealed that postoperative nutritional and immune indexes of patients in EOF group were higher than those in LOF group, especially in POD 7 and POD 30. And inflammatory response is one of the main manifestations of postoperative. Variations in serum inflammatory cytokines can objectively reflect the state of postoperative inflammatory response of patients [27]. The CRP and IL-6 levels in EOF group were lower than LOF in POD7 and POD30, which suggested that early oral feeding led the inflammatory response subside faster. Furthermore, variations in digestive tract structure and dietary habits after surgery result severe weight loss of severe skeletal muscle [28]. The body weight loss and T12-SMA
Table 3 Nutrition index of the two groups

\begin{tabular}{|c|c|c|c|}
\hline Nutrition index & EOF $(n=67)$ & $\operatorname{LOF}(n=54)$ & $p$ value \\
\hline \multicolumn{4}{|l|}{ Preoperative } \\
\hline ALB (g/L) & $42.74 \pm 4.27$ & $43.15 \pm 4.68$ & 0.616 \\
\hline $\mathrm{PA}(\mathrm{mg} / \mathrm{L})$ & $301.62 \pm 77.13$ & $295.28 \pm 84.32$ & 0.667 \\
\hline TRF (g/L) & $2.12 \pm 0.36$ & $2.06 \pm 0.22$ & 0.285 \\
\hline $\mathrm{Hb}(\mathrm{g} / \mathrm{L})$ & $131.83 \pm 19.71$ & $133.21 \pm 24.37$ & 0.737 \\
\hline \multicolumn{4}{|l|}{ POD 1} \\
\hline ALB (g/L) & $34.86 \pm 3.15$ & $35.27 \pm 3.72$ & 0.513 \\
\hline PA (mg/L) & $261.54 \pm 35.64$ & $267.36 \pm 43.39$ & 0.423 \\
\hline TRF (g/L) & $1.48 \pm 0.23$ & $1.52 \pm 0.31$ & 0.417 \\
\hline $\mathrm{Hb}(\mathrm{g} / \mathrm{L})$ & $119.86 \pm 12.76$ & $121.49 \pm 18.43$ & 0.567 \\
\hline \multicolumn{4}{|l|}{ POD 3} \\
\hline ALB (g/L) & $34.36 \pm 2.64$ & $34.73 \pm 2.17$ & 0.409 \\
\hline $\mathrm{PA}(\mathrm{mg} / \mathrm{L})$ & $178.62 \pm 22.12$ & $185.73 \pm 28.75$ & 0.127 \\
\hline $\operatorname{TRF}(\mathrm{g} / \mathrm{L})$ & $1.21 \pm 0.23$ & $1.17 \pm 0.11$ & 0.243 \\
\hline $\mathrm{Hb}(\mathrm{g} / \mathrm{L})$ & $108.26 \pm 15.64$ & $105.91 \pm 12.53$ & 0.372 \\
\hline \multicolumn{4}{|l|}{ POD 7} \\
\hline ALB (g/L) & $36.74 \pm 3.22$ & $36.02 \pm 3.64$ & 0.257 \\
\hline $\mathrm{PA}(\mathrm{mg} / \mathrm{L})$ & $208.62 \pm 27.12$ & $195.37 \pm 32.78$ & $0.016^{*}$ \\
\hline TRF (g/L) & $1.30 \pm 0.18$ & $1.26 \pm 0.11$ & 0.155 \\
\hline $\mathrm{Hb}(\mathrm{g} / \mathrm{L})$ & $110.36 \pm 12.34$ & $106.24 \pm 18.67$ & 0.148 \\
\hline \multicolumn{4}{|l|}{ POD 30} \\
\hline ALB (g/L) & $39.67 \pm 3.16$ & $38.14 \pm 3.83$ & $0.018^{*}$ \\
\hline $\mathrm{PA}(\mathrm{mg} / \mathrm{L})$ & $248.96 \pm 47.85$ & $211.38 \pm 55.23$ & $0.004^{*}$ \\
\hline TRF (g/L) & $1.89 \pm 0.42$ & $1.72 \pm 0.35$ & $0.019 *$ \\
\hline $\mathrm{Hb}(\mathrm{g} / \mathrm{L})$ & $119.95 \pm 14.02$ & $112.06 \pm 18.73$ & $0.009 *$ \\
\hline
\end{tabular}

Note: ${ }^{*}-P<0.05$

variation were less in EOF group. Lastly, QLQ-C30 scores of the EOF group were also higer than those in LOF group. Previous studies have proved that early oral feeding can protect the intestinal mucosal barrier of patients undergoing gastrointestinal surgery, thus to improve nutrition, immunity, and promote the recovery of intestinal and organ functions [29]. And our results suggested that early oral feeding was a safe intervention for patients of esophageal cancer complicated with type II diabetes.

\section{Conclusion}

In summary, our study retrospectively analyzed the clinical data of 121 patients to explore the safety of early oral feeding in patients of esophageal cancer complicated with type II diabetes. And results showed that early oral feeding could speed up the recovery of nutritional and immune status, decrease the inflammatory response and weight loss of surgery, and meanwhile do not increase the incidence of complications. 
Table 4 Inflammatory index of the two groups

\begin{tabular}{|c|c|c|c|}
\hline Inflammatory index & EOF $(n=67)$ & LOF $(n=54)$ & $p$ value \\
\hline \multicolumn{4}{|l|}{ Preoperative } \\
\hline CRP (mg/L) & $2.86 \pm 3.37$ & $3.48 \pm 5.72$ & 0.46 \\
\hline IL-6 (ng/L) & $2.96 \pm 3.17$ & $2.35 \pm 3.89$ & 0.344 \\
\hline \multicolumn{4}{|l|}{ POD 1} \\
\hline $\mathrm{CRP}(\mathrm{mg} / \mathrm{L})$ & $52.34 \pm 10.24$ & $55.12 \pm 13.36$ & 0.198 \\
\hline IL-6 (ng/L) & $202.64 \pm 95.51$ & $194.12 \pm 88.23$ & 0.615 \\
\hline \multicolumn{4}{|l|}{ POD 3} \\
\hline CRP (mg/L) & $149.78 \pm 57.86$ & $156.31 \pm 46.14$ & 0.502 \\
\hline IL-6 (ng/L) & $58.36 \pm 29.68$ & $61.49 \pm 33.72$ & 0.588 \\
\hline \multicolumn{4}{|l|}{ POD 7} \\
\hline CRP (mg/L) & $47.58 \pm 25.72$ & $60.87 \pm 30.26$ & $0.01 *$ \\
\hline IL-6 (ng/L) & $19.34 \pm 12.67$ & $26.19 \pm 10.73$ & $0.002^{*}$ \\
\hline \multicolumn{4}{|l|}{ POD 30} \\
\hline CRP (mg/L) & $6.13 \pm 13.25$ & $13.57 \pm 18.96$ & $0.013^{*}$ \\
\hline IL-6 (ng/L) & $5.86 \pm 6.34$ & $10.35 \pm 5.82$ & $0.0001^{*}$ \\
\hline
\end{tabular}

\section{Weakness and expectation}

This study has some limitations. First, the patient data in this study was collected from a single institution database. Therefore, there is a certain degree of selection bias. Second, it includes only a retrospective study, and intrinsic errors and deviations in its design may inevitably affect the results. This study requires further multicenter, large sample, and prospective studies to verify our results. Our research group has continued to collect the number of relevant cases, and the next step is to cooperate with other centers for research.

Table 5 Postoperative complications in the 2 groups

\begin{tabular}{llll}
\hline Postoperative complications & EOF $(\boldsymbol{n}=\mathbf{6 7})$ & LOF $(\boldsymbol{n}=\mathbf{5 4})$ & $\boldsymbol{p}$ value \\
\hline Clavien-Dindo Degree I-II & 17 & 14 & 0.945 \\
Pulmonary infection & 4 & 4 & 0.752 \\
Incision infection & 5 & 3 & 0.675 \\
Gastrointestinal dysfunction & 5 & 4 & 0.991 \\
Injury of recurrent nerve & 3 & 3 & 0.786 \\
Clavien-Dindo Degree III-IV & 8 & 7 & 0.643 \\
Severe pulmonary infection & 1 & 1 & $>0.999$ \\
and respiratory failure & & & \\
Hydropneumothorax & 1 & 0 & 1 \\
Anastomotic fistula & 6 & 5 & 0.954 \\
Anastomotic or thoracic & 0 & 1 & 0.446 \\
bleeding requiring reoperation & & 21 & 0.859 \\
Total & 25 & &
\end{tabular}

Table 6 Postoperative QLQ-C30 scores of the two group

\begin{tabular}{llll}
\hline Items & EOF $(\boldsymbol{n}=\mathbf{6 7})$ & LOF $(\boldsymbol{n}=\mathbf{5 4})$ & $\boldsymbol{p}$ value \\
\hline Functional Rating Scale & & & \\
$\begin{array}{l}\text { physical function } \\
\text { role function }\end{array}$ & $59.12 \pm 17.74$ & $50.35 \pm 16.48$ & $\mathbf{0 . 0 0 6 ^ { * }}$ \\
emotional functioning & $61.17 \pm 15.73$ & $54.98 \pm 12.61$ & $\mathbf{0 . 0 2 \mathbf { 1 } ^ { * }}$ \\
cognitive function & $81.27 \pm 10.11$ & $79.66 \pm 11.89$ & 0.423 \\
social function & $51.62 \pm 15.81$ & $49.39 \pm 16.76$ & 0.454 \\
Symptoms Rating Scale & & & \\
fatigued & $50.82 \pm 19.47$ & $59.16 \pm 18.04$ & $\mathbf{0 . 0 1 7 ^ { * }}$ \\
nausea and vomiting & $22.86 \pm 12.76$ & $24.78 \pm 16.67$ & 0.474 \\
pain & $23.69 \pm 15.95$ & $24.86 \pm 16.59$ & 0.694 \\
anhelation & $18.23 \pm 16.95$ & $19.27 \pm 18.36$ & 0.747 \\
insomnia & $28.66 \pm 16.36$ & $30.64 \pm 17.39$ & 0.521 \\
appetite loss & $27.67 \pm 20.36$ & $38.62 \pm 21.68$ & $\mathbf{0 . 0 0 5 ^ { * }}$ \\
constipation & $19.26 \pm 16.34$ & $17.92 \pm 17.72$ & 0.667 \\
diarrhea & $22.96 \pm 16.08$ & $31.32 \pm 17.79$ & $\mathbf{0 . 0 0 \boldsymbol { B } ^ { * }}$ \\
financial difficulty & $31.82 \pm 24.57$ & $30.67 \pm 22.09$ & 0.79 \\
General health status & $61.33 \pm 10.18$ & $53.96 \pm 14.87$ & $\mathbf{0 . 0 0 1 *}$ \\
\hline Note: *-P<0.05 & & &
\end{tabular}

Note: *-P $<0.05$ 

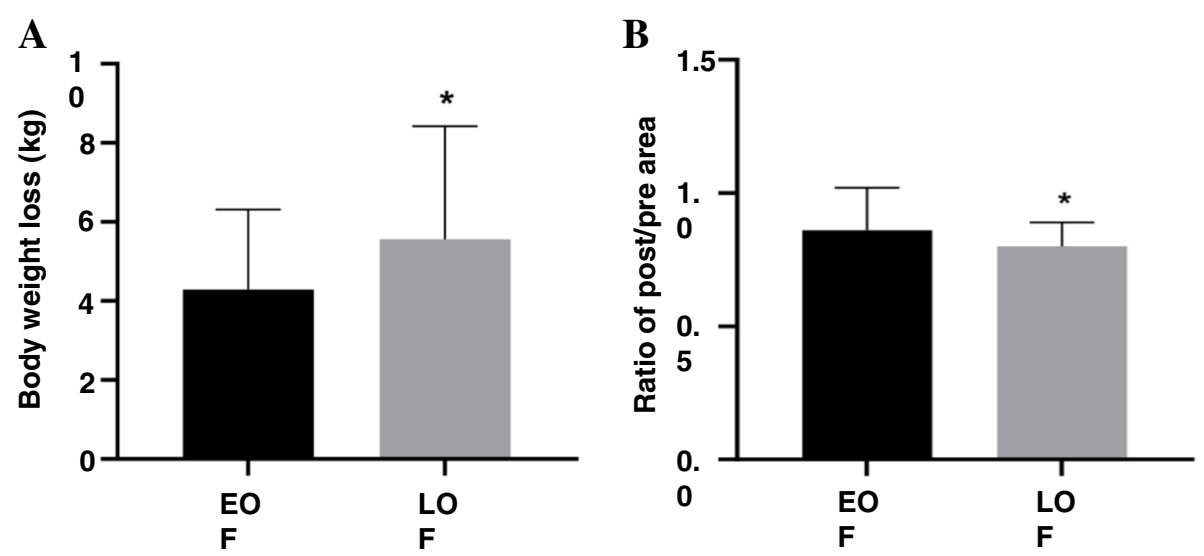

C

Preoperative

\section{Postoperative}

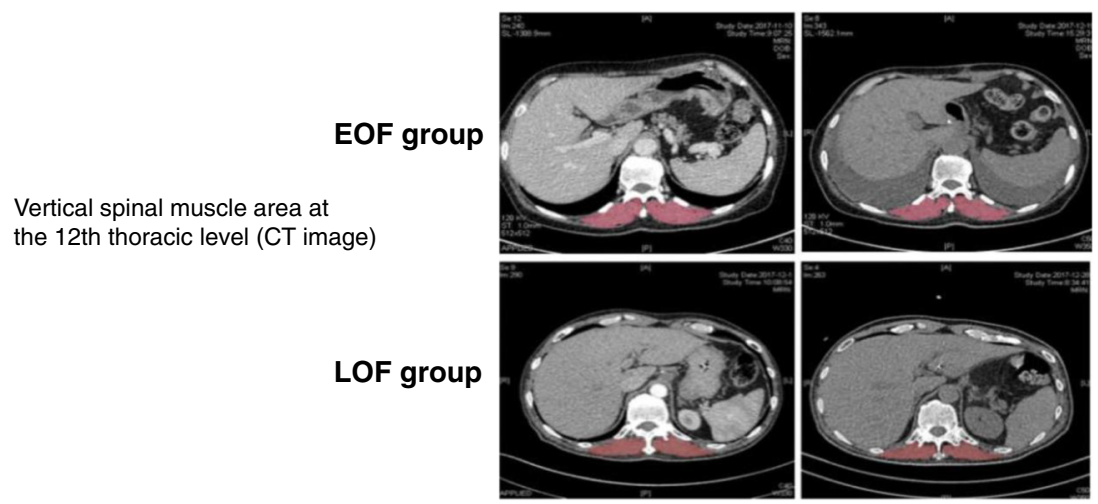

Fig. 2 a The body weight loss of patients in EOF group was lower than that in LOF group in POD 30. b T12-SMA variation was greater in the EOF group. c CT images of calculating T12-SMA were shown

\section{Abbreviations}

EOF: Early oral feeding; LOF: Late oral feeding; QLQ: Quality of Life Questionnaire; ALB: Albumin; PA: Prealbumin; TRF: Transferrin; Hb: Hemoglobin; CRP: C-Reactive Protein; IL-6: Interleukin-6; HbAlc: Glycosylated hemoglobin; EN: Enteral Nutrition; PN: Enteral Nutrition; POD: Postoperative Day; ERAS: Enhanced Recovery After Surgery

\section{Supplementary Information}

The online version contains supplementary material available at https://doi. org/10.1186/s13019-021-01410-4.

Additional file 1: Table S1. Preoperative QLQ-C30 scores of the two group.

\section{Acknowledgements}

The authors declare that there are no conflicts of interest.

\section{Authors' contributions}

Yi Shen designed and supervised the study. Zhisheng Jiang and JingLuo collected the data and wrote the manuscript. Mengqing Xu and

Zhuangzhuang Cong was responsible for statistical analysis. Saiguang Ji, Yifei Diao and Yang Xu provided technical support and helped to refine the manuscript. All authors read and approved the final manuscript.

\section{Funding}

This work was supported by the National Natural Science Foundation of China (No.81172032) and the Natural Science Foundation of Jiangsu
Province (BK20181239). All data generated or analyzed during this study are included in this article and its supplementary information files.

Availability of data and materials Not applicable.

\section{Declarations}

Ethics approval and consent to participate

Not applicable.

\section{Consent for publication}

Not applicable.

Competing interests

Not applicable.

\section{Author details}

${ }^{1}$ Bengbu Medical College, Bengbu, China. ${ }^{2}$ Department of Cardiothoracic Surgery, Jinling Hospital, 305 East Zhongshan Road, Nanjing, China. ${ }^{3}$ Suzhou Hospital Affiliated To Anhui Medical University, Suzhou, Anhui, China.

Received: 3 March 2020 Accepted: 10 March 2021

Published online: 26 March 2021

\section{References}

1. Bray F, Ferlay J, Soerjomataram I, Siegel RL, Torre LA, Jemal A. Global cancer statistics 2018: GLOBOCAN estimates of incidence and mortality worldwide for 36 cancers in 185 countries. CA Cancer J Clin. 2018;68(6):394-424. https://doi.org/10.3322/caac.21492. 
2. Siegel RL, Miller KD, Jemal A. Cancer statistics, 2017. CA Cancer J Clin. 2017; 67(1):7-30. https://doi.org/10.3322/caac.21387.

3. Allemani C, Matsuda T, Di Carlo V, Harewood R, Matz M, Niksic M, Bonaventure A, Valkov M, Johnson CJ, Esteve J, Ogunbiyi OJ, ESG A, Chen WQ, Eser S, Engholm G, Stiller CA, Monnereau A, Woods RR, Visser O, Lim GH, Aitken J, Weir HK, Coleman MP, Group CW. Global surveillance of trends in cancer survival 2000-14 (CONCORD-3): analysis of individual records for 37513025 patients diagnosed with one of 18 cancers from 322 population-based registries in 71 countries. Lancet. 2018;391:1023-75.

4. Qi J, He P, Yao H, Song R, Ma C, Cao M, Cui B, Ning G. Cancer risk among patients with type 2 diabetes: a real-world study in Shanghai, China. J Diabetes. 2019;11(11):878-83. https://doi.org/10.1111/1753-0407.12926.

5. Kovatchev B. A century of diabetes technology: signals, models, and artificial pancreas control. Trends Endocrinol Metab. 2019;30(7):432-44. https://doi. org/10.1016/j.tem.2019.04.008.

6. Hart PA, Law RJ, Frank RD, Bamlet WR, Burch PA, Petersen GM, Rabe KG, Chari ST. Impact of diabetes mellitus on clinical outcomes in patients undergoing surgical resection for pancreatic cancer: a retrospective, cohort study. Am J Gastroenterol. 2014;109(9):1484-92. https://doi.org/10.1038/ajg.2 014.193 .

7. Yao W, Meng Y, Lu M, Fan W, Huang J, Li J, Zhu Z. Impact of type 2 diabetes mellitus on short-term and long-term outcomes of patients with esophageal squamous cell cancer undergoing resection: a propensity score analysis. Cancer Commun (Lond). 2018;38(1):14. https://doi.org/10.1186/s4 0880-018-0275-2.

8. Aminian A, Panahi N, Mirsharifi R, Karimian F, Meysamie A, Khorgami Z, Alibakhshi A. Predictors and outcome of cervical anastomotic leakage after esophageal cancer surgery. J Cancer Res Ther. 2011;7(4):448-53. https://doi. org/10.4103/0973-1482.92016.

9. Li SJ, Wang ZQ, Li YJ, Fan J, Zhang WB, Che GW, Liu LX, Chen LQ. Diabetes mellitus and risk of anastomotic leakage after esophagectomy: a systematic review and meta-analysis. Dis Esophagus. 2017;30(6):1-12. https://doi.org/1 0.1093/dote/dox006.

10. Willcutts KF, Chung MC, Erenberg CL, Finn KL, Schirmer BD, Byham-Gray LD. Early Oral feeding as compared with traditional timing of Oral feeding after upper gastrointestinal surgery: a systematic review and meta-analysis. Ann Surg. 2016;264(1):54-63. https://doi.org/10.1097/SLA.0000000000001644.

11. Sun HB, Li Y, Liu XB, Zhang RX, Wang ZF, Lerut T, Liu CC, Fiorelli A, Chao YK, Molena D, Cerfolio RJ, Ozawa S, Chang AC, written on behalf of the AMETSCG. Early Oral feeding following McKeown minimally invasive Esophagectomy: an open-label, randomized, controlled, noninferiority trial. Ann Surg. 2018;267(3):435-42. https://doi.org/10.1097/ SLA.0000000000002304.

12. Sun HB, Li Y, Liu XB, Wang ZF, Zhang RX, Lerut T, Zheng Y, Liu SL, Chen XK. Impact of an early Oral feeding protocol on inflammatory cytokine changes after Esophagectomy. Ann Thorac Surg. 2019;107(3):912-20. https://doi. org/10.1016/j.athoracsur.2018.09.048.

13. Liu $X B$, Xing $W Q$, Sun $H B$. Early oral feeding following esophagectomy. J Thorac Dis. 2019;11(S5):S824-30. https://doi.org/1 0.21037/jtd.2019.01.24.

14. Mboumi IW, Reddy S, Lidor AO. Complications after Esophagectomy. Surg Clin North Am. 2019;99(3):501-10. https://doi.org/10.1016/j.suc.2 019.02.011.

15. de Jong R, Peeters P, Burden AM, de Bruin ML, Haak HR, Masclee AAM, de Vries F, Janssen-Heijnen MLG. Gastrointestinal cancer incidence in type 2 diabetes mellitus; results from a large population-based cohort study in the UK. Cancer Epidemiol. 2018;54:104-11. https://doi.org/10.1 016/j.canep.2018.04.008

16. Kassis ES, Kosinski AS, Ross P Jr, Koppes KE, Donahue JM, Daniel VC. Predictors of anastomotic leak after esophagectomy: an analysis of the society of thoracic surgeons general thoracic database. Ann Thorac Surg. 2013;96(6):1919-26. https://doi.org/10.1016/j.athoracsur.2013.07.119.

17. Richards JE, Kauffmann RM, Zuckerman SL, Obremskey WT, May AK. Relationship of hyperglycemia and surgical-site infection in orthopaedic surgery. J Bone Joint Surg Am. 2012;94(13):1181-6. https://doi.org/10.2106/ JBJS.K.00193.

18. Fearon KC, Luff R. The nutritional management of surgical patients: enhanced recovery after surgery. Proc Nutr Soc. 2003;62(4):807-11. https:// doi.org/10.1079/PNS2003299.

19. Fearon $\mathrm{KC}$, Ljungqvist O, Von Meyenfeldt M, Revhaug A, Dejong CH, Lassen K, Nygren J, Hausel J, Soop M, Andersen J, Kehlet H. Enhanced recovery after surgery: a consensus review of clinical care for patients undergoing colonic resection. Clin Nutr. 2005;24(3):466-77. https://doi.org/10.1016/j. clnu.2005.02.002.

20. Nishi M, Hiramatsu Y, Hioki K, Kojima Y, Sanada T, Yamanaka H, Yamamoto M. Risk factors in relation to postoperative complications in patients undergoing esophagectomy or gastrectomy for cancer. Ann Surg. 1988;207(2):148-54. https://doi.org/10.1097/00000658-1 98802000-00006.

21. Backemar L, Djarv T, Wikman A, Johar A, Ross P, Lagergren P, Lagergren J. The role of diabetes and other co-morbidities on survival after esophageal cancer surgery in a population-based study. Am J Surg. 2013;206(4):539-43. https://doi.org/10.1016/j.amjsurg.2013.01.035.

22. Cerantola $Y$, Valerio M, Persson B, Jichlinski P, Ljungqvist $O$, Hubner M, Kassouf W, Muller S, Baldini G, Carli F, Naesheimh T, Ytrebo L, Revhaug A, Lassen K, Knutsen T, Aarsether E, Wiklund P, Patel HR. Guidelines for perioperative care after radical cystectomy for bladder cancer: enhanced recovery after surgery (ERAS((R))) society recommendations. Clin Nutr. 2013;32(6):879-87. https://doi.org/10.101 6/j.clnu.2013.09.014.

23. Tweed T, van Eijden $Y$, Tegels J, Brenkman H, Ruurda J, van Hillegersberg R, Sosef M, Stoot J. Safety and efficacy of early oral feeding for enhanced recovery following gastrectomy for gastric cancer: a systematic review. Surg Oncol. 2019;28:88-95. https://doi.org/10.1016/j.suronc.2018.11.017.

24. Robertson TR, Eldridge NE, Rattray ME, Roberts SJ, Desbrow B, Marshall AP, Ali $A B$, Hickman IJ. Early oral feeding after colorectal surgery: a mixed methods study of knowledge translation. Nutr Diet. 2018;75(4):345-52. https://doi.org/10.1111/1747-0080.12473.

25. Berkelmans GHK, Fransen L, Weijs TJ, Lubbers M, Nieuwenhuijzen GAP, Ruurda JP, Kouwenhoven EA, van Det MJ, Rosman C, van Hillegersberg R, Luyer MDP. The long-term effects of early oral feeding following minimal invasive esophagectomy. Dis Esophagus. 2018;31(1):1-8. https://doi.org/10.1 093/dote/dox114.

26. Nakamura Y, Momoki C, Okada G, Matsumoto Y, Yasui Y, Habu D, Matsuda $\mathrm{Y}$, Lee S, Osugi H. Preoperative depressive mood of patients with esophageal Cancer might delay recovery from operation-related malnutrition. J Clin Med Res. 2019;11(3):188-95. https://doi.org/10.14740/ jocmr3704.

27. Matsunaga T, Miyata $H$, Sugimura $K$, Motoori M, Asukai $K$, Yanagimoto $Y$, Takahashi Y, Tomokuni A, Yamamoto K, Akita H, Nishimura J, Wada H, Takahashi H, Yasui M, Omori T, Oue M, Yano M. Prognostic significance of sarcopenia and systemic inflammatory response in patients with esophageal Cancer. Anticancer Res. 2019;39(1):449-58. https://doi.org/10.21 873/anticanres.13133.

28. Baker M, Halliday V, Williams RN, Bowrey DJ. A systematic review of the nutritional consequences of esophagectomy. Clin Nutr. 2016;35(5):987-94. https://doi.org/10.1016/j.clnu.2015.08.010.

29. Sierzega M, Choruz R, Pietruszka S, Kulig P, Kolodziejczyk P, Kulig J. Feasibility and outcomes of early oral feeding after total gastrectomy for cancer. J Gastrointest Surg. 2015;19(3):473-9. https://doi.org/10.1007/s11605014-2720-0.

\section{Publisher's Note}

Springer Nature remains neutral with regard to jurisdictional claims in published maps and institutional affiliations.
Ready to submit your research? Choose BMC and benefit from:
- fast, convenient online submission
- thorough peer review by experienced researchers in your field
- rapid publication on acceptance
- support for research data, including large and complex data types
- gold Open Access which fosters wider collaboration and increased citations
- maximum visibility for your research: over $100 \mathrm{M}$ website views per year
At BMC, research is always in progress.
Learn more biomedcentral.com/submissions 